JMI Vol. 41 No. 1, Juni 2019

\author{
METAL INDONESIA \\ Jounal Homepage: \\ http://www.jurnalmetal.or.id/index.php/jmi \\ p-issn: 0126-3463 \\ e-issn: 2548-673X
}

\title{
PENINGKATAN KOERSIVITAS DAN REMANEN PADA MAGNET PERMANEN Nd-Fe-B DENGAN PROSES DIFUSI BATAS BUTIR
}

\section{COERCIVITY AND REMANENCE ENHANCEMENT OF Nd-Fe-B PERMANENT MAGNET BY GRAIN BOUNDARY DIFFUSION PROCESS}

\author{
Martin Doloksairbu*1, Shinta Virdhian*, Dagus Resmana Djuanda* dan Eva Afrilinda* \\ Balai Besar Logam dan Mesin, Jalan Sangkuriang Nomor 12 Bandung 40135, Jawa Barat, Indonesia \\ Email': martin-d@kemenperin.go.id \\ *Kontributor Utama
}

\begin{abstract}
Abstrak
Salah satu karakteristik magnet permanen tipe NdFeB adalah rentan terhadap kenaikan temperatur, seperti halnya yang terjadi pada aplikasi motor listrik. Penambahan unsur Dy pada tipe ini menjadi penting dalam usaha meningkatkan koersivitas dan temperatur curie. Akan tetapi, penambahan unsur Dy secara konvensional memerlukan biaya tinggi serta terjadinya penurunan nilai sifat remanen. Penelitian ini dilakukan dengan tujuan menambahkan unsur Dy untuk meningkatkan koersivitas magnet permanen dengan cara difusi batas butir dengan biaya yang lebih rendah dari pada cara konvensional dan tidak menurunkan sifat remanen secara signifikan. Penelitian ini dimulai dengan mengkarakterisasi dan mengamati struktur mikro awal dari magnet permanen tipe NdFeB dengan alat SEM-BSE dan VSM. Kemudian dilakukan proses difusi Dy dengan cara melapisi permukaan magnet dengan campuran $\mathrm{DyF}_{3}-$ LiF dengan variasi perbandingan 0\%-0\% (tanpa lapisan); 44\%-56\% dan 100\%-0\%. Setelah itu, pada setiap variasi lapisan dilakukan perlakuan panas anil $750^{\circ} \mathrm{C}$ dengan variasi waktu penahanan selama 2,$5 ; 5 ; 7,5$ dan 10 jam yang diikuti dengan post anil $550^{\circ} \mathrm{C}$ selama 1 jam. Hasilnya, nilai koersivitas magnet meningkat dari 10,7 kOe menjadi 13,5 kOe pada sampel yang dianil pada variasi waktu penahanan 5 dan 7,5 jam. Sedangkan nilai remanen juga terjadi peningkatan dari 13,2 kG menjadi 14,7 $\mathrm{kG}$ pada sampel yang di anil dengan waktu penahanan selama $10 \mathrm{jam}$. Energi maksimum produk magnet pada sampel yang mengalami proses difusi (43,6 MGOe) lebih tinggi dari sampel yang tidak dilakukan difusi batas butir (43,1 MGOe).
\end{abstract}

Kata kunci : difusi batas butir, dysprosium (Dy), koersivitas, magnet $\mathrm{NdFeB}$, remanen

\begin{abstract}
One of the characteristics of the NdFeB type permanent magnet was susceptible against the increase of temperature such as in electric motor applications. It is important to add Dy elements to increase coercivity and temperature curie. However, the addition of Dy elements conventionally requires high costs and reduces remanent significantly. The purpose of this study was to improve coercivity without a significant decrease in remanence by adding Dy elements with grain boundary diffusion. The microstructure of the NdFeB type permanent magnet was characterized and observed with SEM-BSE and VSM. Then, the surface of NdFeB type permanent magnet was coated with DyFLiF with variation ratio of 0\%-0\% (without coating); 44\%-56\% and 100\%-0\%. After that, each variation was annealed at $750^{\circ} \mathrm{C}$ for holding time of 2.5; 5; 7.5 and 10 hours followed by post-annealing $550^{\circ} \mathrm{C}$ for 1 hour. As a result, the magnetic coercivity increase from $10.7 \mathrm{kOe}$ (initial magnet) to 13.5 $k O e$ at variation of holding time of 5 and 7.5 hours. While the remanence also increased from $13.2 \mathrm{kG}$
\end{abstract}


(initial magnet) to $14.7 \mathrm{kG}$ at 10 hours time. The maximum energy products was increase from 43.1 at sample without coating to 43.6 MGOe at sampel with $100 \% D y F_{3}$.

Keywords : grain boundary diffusion, dysprosium (Dy), coercivity, $\mathrm{Nd}-\mathrm{Fe}-\mathrm{B}$ magnet, remanence

\section{PENDAHULUAN}

Saat ini kendaraan listrik dan kendaraan hibrid mendapatkan banyak perhatian terkait dengan pengurangan penggunaan bahan bakar fosil. Tenaga penggerak kendaraan listrik dihasilkan akibat interaksi antara arus listrik dan medan magnet. Sifat magnet permanen pada mesin memberikan pengaruh terhadap besar tenaga penggerak yang dihasilkan

Magnet Permanen berbasis Logam Tanah Jarang (LTJ) memiliki sifat magnet lebih baik dibandingkan Magnet Permanen yang terbuat dari besi, baja dan keramik. Magnet Permanen berbasis LTJ memiliki nilai (BH)max magnet mencapai 30 35 MGOe atau 240 280 kJ.m-3 (Idayanti, Manaf, and Dedi 2018). Dengan nilai $\mathrm{BH}(\max )$ tersebut, magnet permanen berbasis LTJ mampu memenuhi tuntutan produk yang mengutamakan miniaturisasi ruang.

Magnet Permanen NdFeB menjadi komponen yang penting pada motor listrik dan power generator. Magnet permanen $\mathrm{Nd}-\mathrm{Fe}-\mathrm{B}$ memiliki koersivitas sebesar $20 \mathrm{kOe}$, magnet remanen 1,2 $\mathrm{T}$ dan energi maksimum produk mencapai 34 40,7 MGOe (Jin et al. 2016). Namun magnet permanen berbasis $\mathrm{NdFeB}$ tergantung terhadap temperatur tinggi. Nilai BHmax magnet $\mathrm{NdFeB}$ akan menurun drastis saat temperatur mencapai $99,85^{\circ} \mathrm{C}(373 \mathrm{~K})$ (Cui et al. 2018). Nilai BHmax $\mathrm{NdFeB}$ perlu ditingkatkan agar nilai magnet yang tersedia masih mencukupi ketika temperatur operasi mencapai $373 \mathrm{~K}$.

Sifat magnet $\mathrm{NdFeB}$ dapat ditingkatkan dengan menggunakan unsur LTJ seperti Dy dan Pr. Namun kelangkaan Dy dan Pr menyebabkan harga LTJ tersebut sangat mahal (Sheridan et al. 2014; Pavel et al. 2017). Alternatifnya adalah dengan menggunakan metode difusi batas butir sehingga Dy yang digunakan lebih sedikit.

Proses difusi batas butir dapat mensubsitusikan sebagian Nd dengan unsur Dy. Penelitian Liu et al. telah meningkatkan koersivitas magnet Dy free Nd-Fe-B hot deformed. Koersivitas ditingkatkan dengan mendifusikan paduan $\mathrm{Nd}-\mathrm{Ga}-\mathrm{Cu}$ dan $\mathrm{Nd}-\mathrm{Fe}-\mathrm{Ga}-$ $\mathrm{Cu}$ pada temperatur $600^{\circ} \mathrm{C}$ selama 3 jam. Magnet $\mathrm{NdFeB}$ menghasilkan koersivitas sebesar 2,2 T dan magnet remanen sekitar 1,3 1,08 $\mathrm{T}$ dari koersivitas sekitar $1,8 \quad \mathrm{~T} \quad\left(\begin{array}{lll}18 & \mathrm{kOe}\end{array}\right)$ pada temperatur ruang (Liu et al. 2018). Sedangkan pada aplikasi traction motors pada kendaraan elektrik atau hybrid diperlukan koertivitas di atas $0,8 \mathrm{~T}$ pada temperatur $180^{\circ} \mathrm{C}$. Oleh karena itu dibutuhkan sekitar $3 \mathrm{~T}$ pada temperatur ruang. Struktur mikro mempengaruhi koersivitas dan remanen magnet permanen. Formasi fasa intergranular non ferromagnetik kaya Nd pada struktur mikro meningkatkan koersivitas namun menurunkan remanen. Penggunaan unsur yang berbeda dapat menimbulkan efek yang berbeda.

Temperatur annealing dan waktu tahan merupakan parameter yang penting untuk mencapai penyisipan yang optimal pada batas butir. Pratomo et al. melakukan proses GBD dengan unsur Dy dan $\mathrm{Tb}$ pada temperatur annealing $800 \sim 1050^{\circ} \mathrm{C}$ dengan waktu tahan 2 jam. Liu et al. menggunakan paduan $\mathrm{Nd}-\mathrm{Ga}-\mathrm{Cu}$ dan $\mathrm{Nd}-\mathrm{Fe}-\mathrm{Ga}-\mathrm{Cu}$ pada temperatur $600^{\circ} \mathrm{C}$ dengan waktu tahan 3 jam. Penggunaan unsur paduan dapat memberikan alternatif temperatur annealing yang lebih rendah.

Post-sinter annealing memberikan efek peningkatan yang berbeda. Lit et al. menyebutkan bahwa koersivitas dapat ditingkatkan dari $1 \mathrm{~T}$ menjadi 1,8 $\mathrm{T}$ dengan postsinter annealing di atas $480^{\circ} \mathrm{C}$. Hasil tersebut lebih besar dari magnet yang disinter secara standar.

Penelitian ini bertujuan untuk meningkatkan sifat magnet komersil Nd-Fe-B dengan metode difusi batas butir menggunakan paduan $\mathrm{DyF}_{3}-\mathrm{LiF}$. Metode ini menggunakan sedikit paduan $\mathrm{DyF}_{3}-\mathrm{LiF}$ sehingga biaya yang diperlukan lebih sedikit. Melalui penelitian ini dapat mengetahui pengaruh paduan $\mathrm{DyF}_{3}-\mathrm{LiF}$ dengan metode difusi batas butir terhadap peningkatan koersivitas, magnet remanen dan energi produk maksimum magnet $\mathrm{Nd}-\mathrm{Fe}-\mathrm{B}$ dengan metode difusi batas butir.

\section{METODOLOGI}

Subsitusi Nd dilakukan pada Nd yang berada pada batas butir. Pratomo et al. telah melakukan metode GBD dengan menggunakan unsur Dy dan $\mathrm{Tb}$ (Pratomo, Oktadinata, and Pawawoi 2017). Pada penelitian ini menggunakan paduan $\mathrm{DyF}_{3}-\mathrm{LiF}$. 
Sampel dipotong sebesar $3 \times 3 \times 2 \mathrm{~mm}$. Magnet awal dikarakterisasi dengan alat Vibrating Sampel Magnetometer (VSM) untuk mengetahui nilai koersivitas $\left(\mathrm{iH}_{\mathrm{c}}\right)$, medan magnet $\left(\mathrm{M}_{\mathrm{r}}\right)$ dan energi produk maksimum $(\mathrm{BH}$ Max). Magnet awal dianalisa struktur mikro dan kandungan unsur dengan alat Scanning Electron Microscopy-Back Scattered Electron (SEM BSE) Image Hitachi SU 3500 dan X-Ray Diffraction (XRD). Sampel magnet diberikan lapisan dengan variasi $\mathrm{DyF}_{3}-\mathrm{LiF}: 0 \%-0 \%$ (tidak dilapisi); 44\%-56\% dan 100\%-0\%. Sampel yang telah dilapisi diberikan perlakukan panas annealing pada temperatur $750^{\circ} \mathrm{C}$ pada waktu tahan 2,5 jam; 5 jam; 7,5 jam dan 10 jam dalam keadaan vakum pada alat Tungku Perlakuan Panas MTI Corporation GSL 1500X. Setelah annealing, sampel diberikan perlakuan panas post annealing pada temperatur $500^{\circ} \mathrm{C}$ dengan waktu tahan 1 jam pada keadaan vakum. Magnet yang telah diberikan perlakuan panas dikarakterisasi sifat magnetnya dengan alat VSM. Diagram alir penelitian ditunjukkan pada Gambar 1.

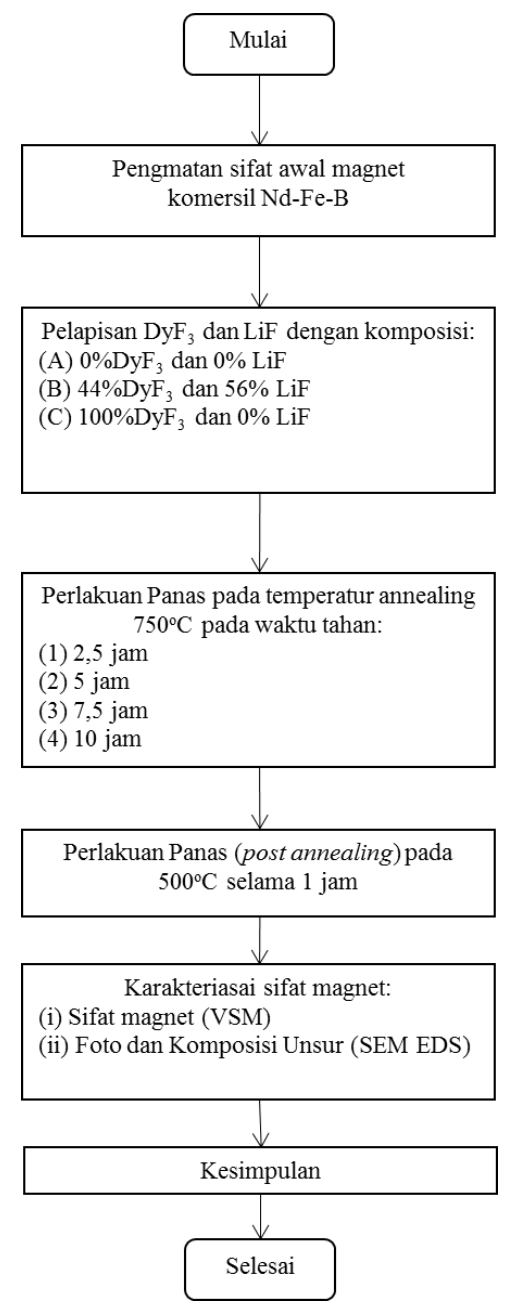

Gambar 1. Diagram alir penelitian

\section{HASIL DAN PEMBAHASAN}

Magnet komersil sebagai bahan magnet awal dikarakterisasi dengan VSM. Hasil karaterisasi dengan VSM ditunjukkan pada Tabel 1.

Tabel 1. Karakterisasi sifat magnet awal menggunakan VSM

\begin{tabular}{ll}
\hline $\mathrm{M}_{15}$ & $14.4 \mathrm{kG}$ \\
$\mathrm{Mr}$ & $13.2 \mathrm{kG}$ \\
$\mathrm{iHc}$ & $10.7 \mathrm{kOe}$ \\
$\mathrm{Mr}$ correction & $13.8 \mathrm{kG}$ \\
$\mathrm{N}_{\mathrm{D}}$ & 0.33 \\
$(\mathrm{BH}) \max$ & $43.6 \mathrm{MGOe}$ \\
\hline
\end{tabular}

Keterangan: $\mathrm{M}_{15}$ : nilai medan magnet pada applied field $15 \mathrm{kOe} ; \mathrm{Mr}$ : medan magnet remanen; $\mathrm{N}_{\mathrm{D}}$ : faktor demagnetisasi

Sumber: dokumentasi penelitian

Magnet awal memiliki medan magnet sebesar $14,4 \mathrm{kG}$ pada applied field $15 \mathrm{kOe}$. Nilai remanen dan koersivitas magnet awal sebesar $13,2 \mathrm{kG}$ dan $10,7 \mathrm{kOe}$.

Magnet awal dianalisa struktur mikro dan komposisi unsur menggunakan BSE Image dan XRD. Hasil analisa ditunjukkan Gambar 2, Gambar 3 dan Tabel 2.

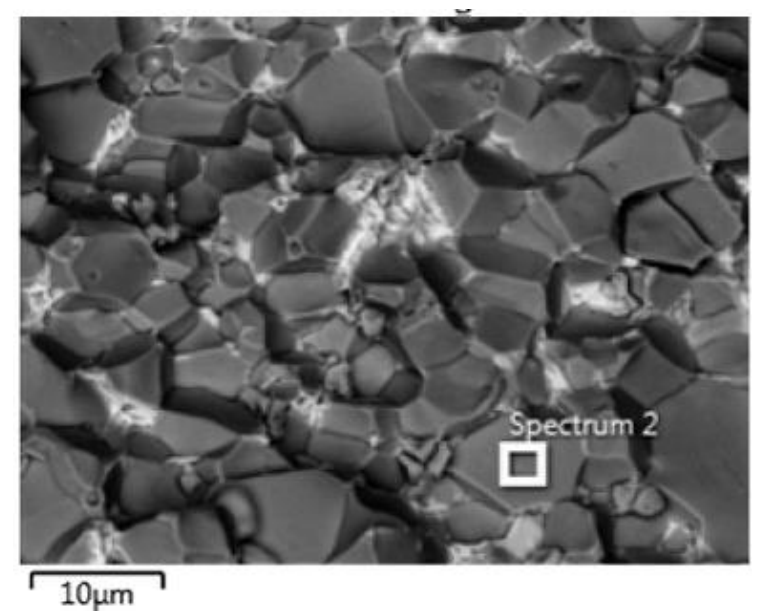

Gambar 2. Electron Image magnet awal menggunakan SEM

Sumber: dokumentasi penelitian 


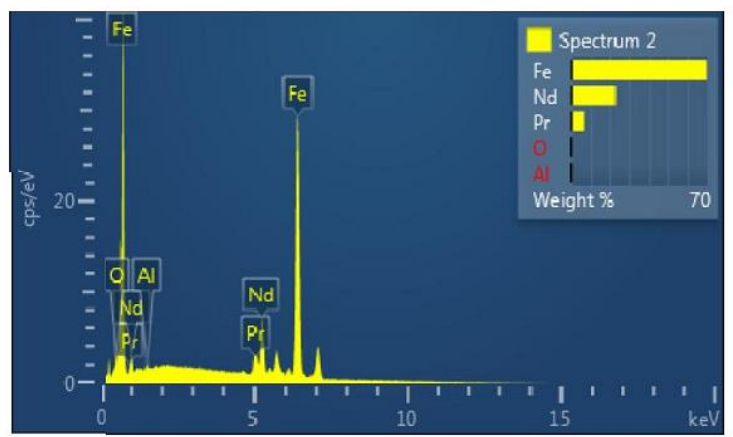

Gambar 3. Hasil pengamatan dengan XRD Sumber: dokumentasi penelitian

Tabel 2. Kandungan unsur magnet awal

\begin{tabular}{llrlr}
\hline Element & Line Type & $\begin{array}{c}\text { Apparent } \\
\text { Concentration }\end{array}$ & k Ratio & Wt\% \\
\hline $\mathrm{O}$ & K series & 0.41 & 0.00137 & 0.20 \\
$\mathrm{Al}$ & K series & 0.13 & 0.00092 & 0.16 \\
$\mathrm{Fe}$ & K series & 54.76 & 0.54757 & 69.60 \\
$\mathrm{Pr}$ & L series & 5.07 & 0.05075 & 7.11 \\
$\mathrm{Nd}$ & L series & 16.40 & 0.16404 & 22.92 \\
Total & & & & 100.00 \\
\hline
\end{tabular}

Sumber: dokumentasi penelitian

Magnet awal mengandung unsur tanah jarang 7,11\%wt Praseodimium (Pr) dan 22,92\%wt Neodimium (Nd). Bahan magnet permanen dengan kandungan $\mathrm{Nd}$ dan $\mathrm{Pr}$ merupakan magnet permanen dengan energi produk yang tinggi (Havwini, Humaidi, and Muljadi 2013).

Magnet dipotong dengan dimensi $3 \times 3 \times 2$ mm. Kode sampel magnet dan perlakuan panas annealing yang diberikan ditunjukkan pada Tabel 3. Magnet awal (as sintered) diberikan temperatur annealing pada waktu tahan 7,5 jam. Sampel A, B dan C diberikan temperatur annealing pada waktu tahan 2,$5 ; 5 ; 7,5$ dan 10 jam.

Tabel 3. Kode sampel, komposisi lapisan dan waktu tahan pada annealing $750 \mathrm{oC}$

\begin{tabular}{ccccccc}
\hline $\begin{array}{c}\text { Kode } \\
\text { Sampel }\end{array}$ & \multicolumn{2}{c}{$\begin{array}{c}\text { Komposisi } \\
\% \text { mol }\end{array}$} & \multicolumn{5}{c}{ Waktu Annealing (jam) } \\
& $\mathrm{DyF}_{3}$ & $\mathrm{LiF}$ & 2,5 & 5 & 7,5 & 10 \\
\hline $\mathrm{A}$ & 0 & 0 & $\bigcirc$ & $\bigcirc$ & $\bigcirc$ & $\bigcirc$ \\
$\mathrm{B}$ & 44 & 56 & $\bigcirc$ & $\bigcirc$ & $\bigcirc$ & $\bigcirc$ \\
C & 100 & 0 & $\bigcirc$ & $\bigcirc$ & $\bigcirc$ & $\bigcirc$ \\
As Sintered & & & & & $\bigcirc$ & \\
\hline Sumber: & dokumentasi penelitian
\end{tabular}

Sumber: dokumentasi penelitian

Hasil karakterisasi sampel as sintered ditunjukkan pada Tabel 4.
Tabel 4. Karakterisasi sifat magnet as sintered

\begin{tabular}{ccccc}
\hline Sampel & $\begin{array}{c}\text { Waktu } \\
\text { Tahan } \\
\text { Jam }\end{array}$ & iHc & Mr & BH max \\
& 7.5 & 10.5 & 13.7 & MGOe \\
\hline As Sintered & 71.2 \\
\hline
\end{tabular}

Sumber: dokumentasi penelitian

Magnet as sintered memiliki koersivitas sebesar 10,5 kOe dan magnet remanen sebesar $13,7 \mathrm{kG}$ pada waktu tahan 7,5 jam.

Hasil karakterisasi sampel A (tanpa pelapisan) dapat dilihat pada Tabel 5 di bawah ini.

Tabel 5. Hasil karakterisasi sampel A (tanpa pelapisan)

\begin{tabular}{ccccc}
\hline Sampel & $\begin{array}{c}\text { Waktu } \\
\text { Tahan } \\
\text { Jam }\end{array}$ & kOe & kG & MGOe \\
\hline No Coating & 2.5 & 12.2 & 14.2 & 42.7 \\
& 5.0 & 13.3 & 13.6 & 39.7 \\
& 7.5 & $\mathbf{1 3 . 5}$ & 13.0 & 41.6 \\
& 10.0 & 13.0 & $\mathbf{1 4 . 5}$ & $\mathbf{4 3 . 1}$ \\
\hline
\end{tabular}

Sumber: dokumentasi penelitian

Koersivitas magnet permanen tanpa pelapisan meningkat dari waktu tahan 2,5 jam s/d 7,5 jam yaitu 12,2; 13,3 dan 13,5 kOe. Koersivitas kemudian menurun pada waktu tahan 10 jam yaitu 13 kOe. Tren magnet remanen $\left(\mathrm{M}_{\mathrm{r}}\right)$ berbeda dengan tren koersivitas. $\mathrm{M}_{\mathrm{r}}$ menurun dari waktu tahan 2,5 jam s/d 7,5 jam yaitu 14,2; 13,6 dan 13,0 kG kemudian meningkat pada waktu tahan 10 jam yaitu 14,5 $\mathrm{kG}$. Energi produk maksimum terdapat pada waktu tahan 10 jam yaitu 43,1 MGOe.

Hasil karaterisasi magnet permanen sampel B dapat dilihat pada Tabel 6 di bawah ini.

Tabel 6. Hasil karakterisasi sampel B pelapisan $44 \%$ DyF3-56\%LiF

\begin{tabular}{ccccc}
\hline \multicolumn{1}{c}{ Sampel } & $\begin{array}{c}\text { Waktu } \\
\text { Tahan } \\
\text { Jam }\end{array}$ & $\mathrm{iHc}$ & $\mathrm{Mr}$ & $\mathrm{BH}$ max \\
& 2.5 & 10.7 & 13.3 & 26.8 \\
\hline 44\% DyF 3 -56\%LiF & 5.0 & $\mathbf{1 3 . 5}$ & 13.8 & $\mathbf{4 0 . 1}$ \\
Eutectic 50\% Liquid & 7.5 & $\mathbf{1 3 . 5}$ & 13.6 & 38.6 \\
& 10.0 & 12.8 & $\mathbf{1 4 . 2}$ & 40.0 \\
\hline
\end{tabular}

Sumber: dokumentasi penelitian

Tren koersivitas magnet permanen Sampel B meningkat dari waktu tahan 2,5 jam s/d 7,5 jam yaitu 10,7; 13,5 dan 13,5 kOe. Koersivitas mengalami penurunan pada waktu tahan 10 jam menjadi 12,8 kOe. Koersivitas tertinggi adalah $13,5 \mathrm{kOe}$ pada waktu tahan 5 dan 7,5 jam. Nilai koersivitas tertinggi sampel B sama dengan nilai koersivitas tertinggi pada 
sampel A (tanpa pelapisan) yaitu 13,5 kOe. Penambahan kandungan $\mathrm{DyF}_{3}$ pada bahan lapisan tidak meningkatkan nilai koersivitas di atas $13,5 \mathrm{kOe}$.

Magnet remanen Sampel B meningkat dari waktu tahan 2,5 jam s/d 5 jam lalu menurun dari waktu tahan 5 jam s/d 7,5 jam kemudian meningkat lagi dari waktu tahan 7,5 jam s/d 10 jam. Nilai $\mathrm{M}_{\mathrm{r}}$ tertinggi yaitu $14,2 \mathrm{kG}$ pada waktu tahan 10 jam. Nilai tersebut lebih kecil dari nilai $\mathrm{M}_{\mathrm{r}}$ tertinggi sampel A. Penggunaan lapisan 44\%DyF3-56\% LiF mampu menurunkan lama waktu tahan untuk mencapai nilai koersivitas sebesar 13,5 kOe walaupun tidak dapat meningkatkan magnet remanen lebih besar dari 14,5 kG (sampel A). Energi produk maksimum paling tinggi dicapai pada waktu tahan 5 jam yaitu 40,1 MGOe. Waktu tersebut lebih cepat dibandingkan pada sampel A.

Penggunaan lapisan $44 \% \mathrm{DyF}_{3}-56 \% \mathrm{LiF}$ pada magnet permanen mampu mencapai koersivitas 13,5 kOe dengan waktu yang lebih singkat. Unsur Dy dapat lebih cepat terdifusi ke matriks Nd-Fe-B dan menggantikan fasa kaya Nd. Penelitian Pratomo et al. menunjukkan bahwa fasa kaya Nd semakin menghilang pada struktur mikro setelah proses difusi batas butir (Pratomo, Oktadinata, and Pawawoi 2017).

Hasil karakterisasi sampel C dapat dilihat pada Tabel 7 di bawah ini.

Tabel 7. Hasil karakterisasi sampel C pelapisan $100 \%$ DyF3

\begin{tabular}{lcccc}
\hline \multicolumn{1}{c}{ Sampel } & $\begin{array}{c}\text { Waktu } \\
\text { Tahan } \\
\text { Jam }\end{array}$ & kOe & kG & MGOe \\
\hline Non Eutectic & 2,5 & 13,3 & 13,1 & 35,9 \\
DyF $_{3}$ & 5,0 & $\mathbf{1 3 , 5}$ & 14,1 & 42,6 \\
& 7,5 & 13,4 & 14,1 & 42,3 \\
& 10,0 & 12,2 & $\mathbf{1 4 , 7}$ & $\mathbf{4 3 , 6}$ \\
\hline
\end{tabular}

Sumber: dokumentasi penelitian

Koersivitas sampel C meningkat lalu menurun dengan bertambah waktu tahan yaitu 13,$3 ; 13,5 ; 13,4$ dan 12,2 kOe. Pada waktu tahan 5 jam, sampel $\mathrm{C}$ menghasilkan koersivitas paling tinggi yaitu 13,5 kOe. Nilai tersebut juga dapat dihasilkan oleh sampel A dan sampel B namun dengan waktu tahan yang berbeda. Pada sampel A (tidak ada pelapisan) koersivitas 13,5 kOe dicapai pada waktu tahan 7,5 jam. Pada sampel B (44\% $\left.\mathrm{DyF}_{3}-56 \% \mathrm{LiF}\right)$ koersivitas $13,5 \mathrm{kOe}$ dicapai pada waktu tahan 5 dan 7,5 jam. Penambahan persentase $\mathrm{DyF}_{3}$ mampu mempertahankan waktu tahan 5 jam untuk menghasilkan koersivitas 13,5 kOe.
Tren magnet remanen sampel $\mathrm{C}$ meningkat dengan peningkatan waktu tahan yaitu 13,$1 ; 14,1 ; 14,1$ dan $14,7 \mathrm{kG}$. Nilai magnet remanen yang dihasilkan sampel $\mathrm{C}$ merupakan nilai magnet remanen paling tinggi dibandingkan sampel A dan sampel B yaitu 14,7 $\mathrm{kG}$ dibandingkan dengan 14,5 (Sampel A) dan 14,2 kG (Sampel B). Energi produk maksimum Sampel C mencapai 43,6 MGOe. Nilai tersebut lebih besar daripada sampel A dan B.

Proses difusi batas butir menggunakan lapisan $\mathrm{DyF}_{3}-\mathrm{LiF}$ mampu meningkatkan koersivitas dari koersivitas magnet as sintered sebesar 10,7 kOe (Gambar 4). Magnet permanen $\mathrm{Nd}-\mathrm{Fe}-\mathrm{B}$ as sintered memiliki koersivitas sebesar 1,1 1,2 $\mathrm{T}$ atau 11 12 kOe (Hono and Sepehri-Amin 2018). Koersivitas dapat ditingkatkan sampai dengan 13,5 kOe. Nilai tersebut dapat dicapai pada waktu tahan 5 jam dengan lapisan $100 \% \mathrm{DyF}_{3}$ (sampel C). Namun koersivitas menurun dengan waktu tahan $10 \mathrm{jam}$.

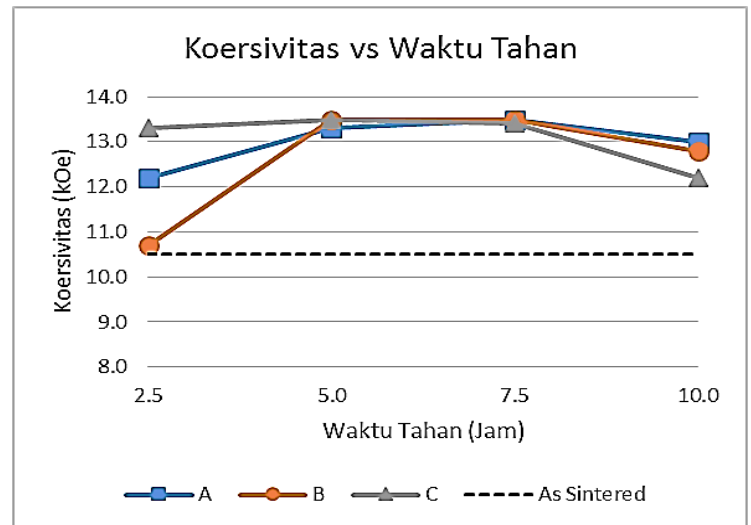

Gambar 4. Grafik koersivitas dan waktu tahan Sumber: dokumentasi penelitian

Beberapa nilai magnet remanen $\left(\mathrm{M}_{\mathrm{r}}\right)$ sampel A, B dan C berada di bawah nilai magnet remanen magnet as sintered (Gambar 5). Magnet remanen as sintered umumnya memiliki $\mathrm{M}_{\mathrm{r}}$ sebesar 1,4 $\mathrm{T}$ atau $14 \mathrm{kOe}$ (Hono and SepehriAmin 2018). Magnet remanen dapat ditingkatkan sampai dengan 14,7 kG. Berbeda dengan koersivitas, magnet remanen pada waktu tahan 10 jam memberikan hasil yang lebih besar dari magnet remanen as sintered. 


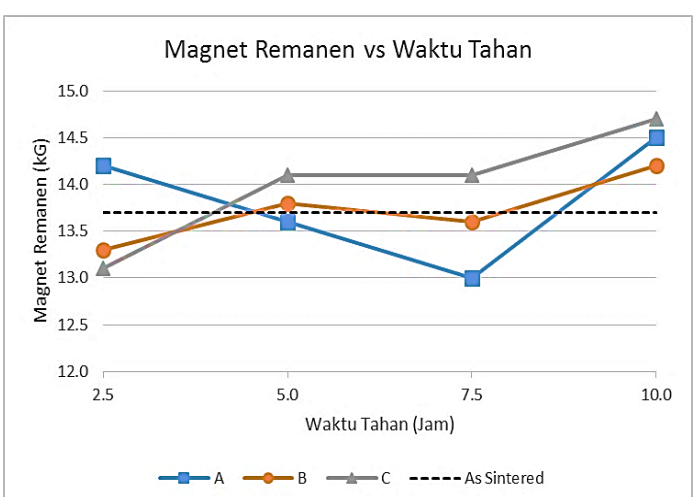

Gambar 5. Grafik magnet remanen terhadap waktu tahan

Sumber: dokumentasi penelitian

Koersivitas dan magnet remanen memiliki hubungan yang saling mempengaruhi. Magnet remanen dapat menurun dengan meningkatnya koersivitas. Semakin rendah magnet remanen maka semakin semakin mudah arah medan magnet berganti arah pada temperatur tinggi. Pada penelitian ini magnet remanen dapat ditingkatkan sampai $14,7 \mathrm{kG}$ pada sampel $\mathrm{C}$ dengan waktu tahan 10 jam. Namun koersivitas sampel $\mathrm{C}$ pada waktu tahan 10 hanya sebesar $12,2 \mathrm{kOe}$.

Pada Gambar 6 dapat dilihat bahwa beberapa nilai energi produk maksimum sampel berada di bawah nilai energi produk maksimum as sintered dan beberapa nilai energi produk maksimum sampel berada di atas energi produk maksimum as sintered. Namun difusi batas butir unsur Dy mampu meningkatkan energi produk maksimum dair 43,1 MGOe pada sampel tanpa lapisan menjadi 43,6 MGOe pada sampel dengan $100 \% \mathrm{DyF}_{3}$.

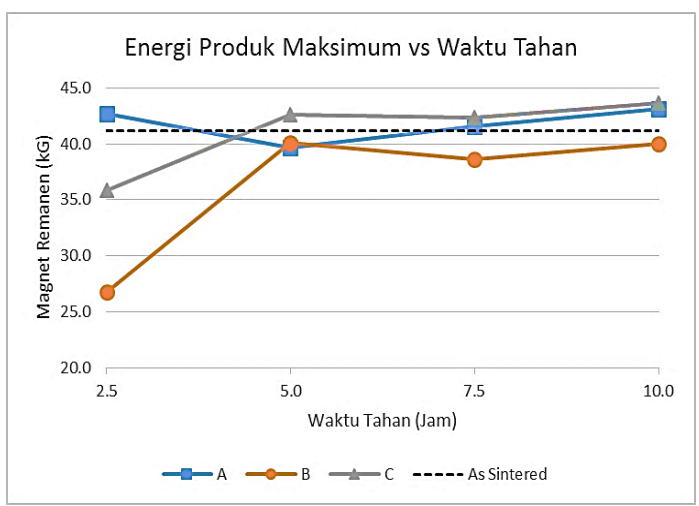

Gambar 6. Grafik energi produk maksimum terhadap waktu tahan

Sumber: dokumentasi penelitian

\section{KESIMPULAN}

Proses difusi batas butir dengan lapisan $\mathrm{DyF}_{3}-\mathrm{LiF}$ dapat meningkatkan sifat magnet komersil as sintered. Koersivitas dapat ditingkatkan dari $10,5 \mathrm{kOe}$ pada sampel as sintered (1,05 T) menjadi 13,5 kOe (1,35 T) pada sampel tanpa lapisan $\mathrm{DyF}_{3}-\mathrm{LiF}$ dengan waktu tahan 7,5 jam; pada sampel dengan $44 \% \mathrm{DyF}_{3}-$ $56 \%$ LiF dengan waktu tahan 5 dan 7,5 jam; dan pada $100 \% \mathrm{DyF}_{3}$ dengan waktu tahan 5 jam. Remanen dapat ditingkatkan dari 13,2 kG (magnet awal) menjadi $14,7 \mathrm{kG}$ pada lapisan $100 \% \mathrm{DyF}_{3}$ dengan waktu tahan 10 jam. Penambahan unsur Dy dengan difusi batas butir dapat meningkatkan energi produk maksimum dari 43,1 MGOe pada sampel tanpa lapisan menjadi 43,6 MGOe pada lapisan $100 \% \mathrm{DyF}_{3}$ dengan waktu tahan 10 jam.

\section{UCAPAN TERIMA KASIH}

Penulis mengucapkan terima kasih kepada Kepala Balai Besar Logam dan Mesin atas bantuan yang diberikan dalam pelaksanaan penelitian ini.

\section{DAFTAR PUSTAKA}

Cui, Jun, Matthew Kramer, Lin Zhou, Fei Liu, Alexander Gabay, George Hadjipanayis, Balamurugan Balasubramanian, and David Sellmyer. 2018. "Current Progress and Future Challenges in Rare-Earth-Free Permanent Magnets." Acta Materialia 158. Elsevier Ltd: 118-37. doi:10.1016/j.actamat.2018.07.049.

Havwini, Tian, Syahrul Humaidi, and Muljadi. 2013. "Analisis Sifat Magnet Dan Mekanik Pada Permanent Bonded Magnet Pr-Fe-B Dengan Matriks Bakelit." Jurnal Saintia Fisika 5 (1). Medan, Indonesia: Universitas Sumatera Utara: 1-6. https://jurnal.usu.ac.id/index.php/sfisika/ar ticle/view/5232/2323.

Hono, K, and H. Sepehri-Amin. 2018. "Prospect for HRE-Free High Coercivity Nd-Fe-B Permanent Magnets." Scripta Materialia 151 (July). Acta Materialia Inc.: 6-13. doi:10.1016/j.scriptamat.2018.03.012.

Idayanti, Novrita, Azwar Manaf, and Dedi. 2018 "Magnet Nanokomposit Sebagai Magnet Permanen Masa Depan." Metalurgi 33 (1). Depok, Indonesia: Pusat Penelitian Metalurgi dan Material LIPI: 1-18. doi:10.14203/metalurgi.v33i1.433.

Jin, Hongyue, Peter Afiuny, Timothy McIntyre, Yuehwern Yih, and John W. Sutherland. 
2016. "Comparative Life Cycle Assessment of $\mathrm{NdFeB}$ Magnets: Virgin Production versus Magnet-to-Magnet Recycling." Procedia CIRP 48. Elsevier B.V.: $45-50$ doi:10.1016/j.procir.2016.03.013.

Liu, Lihua, H. Sepehri-Amin, T. T. Sasaki, T. Ohkubo, M. Yano, N. Sakuma, A. Kato, T. Shoji, and K. Hono. 2018. "Coercivity Enhancement of Nd-Fe-B Hot-Deformed Magnets by the Eutectic Grain Boundary Diffusion Process Using $\mathrm{Nd}-\mathrm{Ga}-\mathrm{Cu}$ and Nd-Fe-Ga-Cu Alloys." AIP Advances 8 (5): 1-8. doi:10.1063/1.5006575.

Pavel, Claudiu C, Roberto Lacal-arántegui, Alain Marmier, Doris Schüler, Evangelos Tzimas, Matthias Buchert, Wolfgang Jenseit, and Darina Blagoeva. 2017. "Substitution Strategies for Reducing the Use of Rare Earths in Wind Turbines." Resources Policy 52 (April). Elsevier Ltd: 349-57. doi:10.1016/j.resourpol.2017.04.010.

Pratomo, Sri Bimo, Herry Oktadinata, and Pawawoi. 2017. "Effect of DyF3 and TbF3 Additions on the Coercivity Enhancement in Grain Boundary Diffusion Processed Nd-Fe-B Permanent Magnets." In Proceedings of the International Seminar on Metallurgy and Materials (ISSM2017), 020019:1-8. American Institute of Physics. doi:10.1063/1.5038301.

Sheridan, R S, A J Williams, I R Harris, and A Walton. 2014. "Improved HDDR Processing Route for Production of Anisotropic Powder from Sintered NdFeB Type Magnets." Journal of Magnetism and Magnetic Materials 350. Elsevier: 114-18. doi:10.1016/j.jmmm.2013.09.042. 